\title{
'n Evaluering van drie interkulturele gemeenskapsprojekte
}

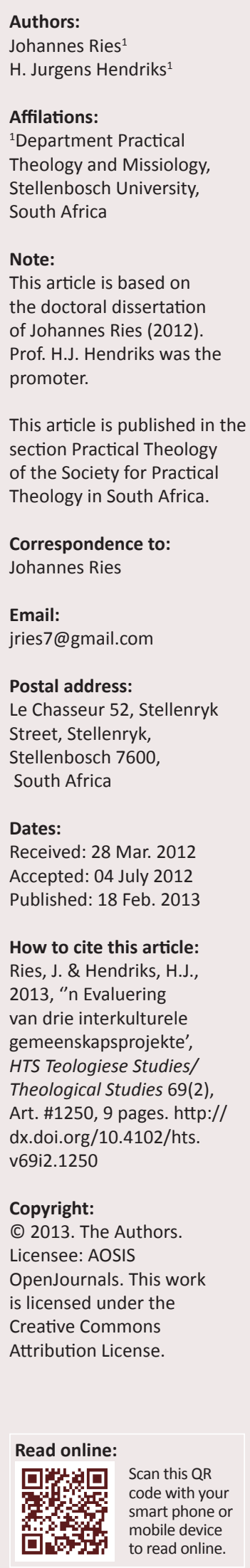

An evaluation of three intercultural community projects. An intercultural framework for servanthood was explored in three Christian community projects. The framework consists of six basic principles, as defined by Duane Elmer, namely openness, acceptance, trust, learning, understanding and serving. This framework is brought into conversation with Miroslav Volf's metaphor of an embrace. In all of this koinonia and diaconia play a pivotal role - especially in the relationship between the two modi. With this hermeneutical framework as point of departure, an empirical study was undertaken to discern the processes and structures within intercultural Christian community projects; and to evaluate the transformation in relationships and the sustainability of the development projects.

\section{Inleiding}

In hierdie artikel word 'n interkulturele raamwerk vir Christelike gemeenskapsprojekte aangebied. Met hierdie raamwerk as uitgangspunt, is 'n empiriese studie aangaande drie Christelike gemeenskapsprojekte onderneem en is daar ondersoek ingestel aangaande die wyse waarop Christelike gemeenskapsprojekte bydra tot ' $n$ sosiale transformasie en meer volhoubare projekte.

Die betrokkenheid by sosiale uitdagings veronderstel 'n besondere missionêre identiteit aan die kant van die Christelike kerk. Bevans en Schroeder (2004:8) voer aan dat die kerk se sending 'n klemverskuiwing vereis vanaf ' $n$ besorgdheid oor die kerk as instelling, na ' $n$ besorgdheid oor die wêreld, sy geskiedenis, kultuur en mense.

August (2000:66) wys daarop dat gemeentelike betrokkenheid by ontwikkeling oor 'n teologiese en kontekstuele dimensie beskik:

1. Teologies gesproke lei die gemeente haar missionêre opdrag af van haar verstaan van God, die mens, die sondeval, redding en die koninkryk van God. Dit veronderstel 'n ontmoeting met God en met die mens (koinonia).

2. Kontekstueel poog die gemeente om deur die ontwikkelingsproses behoeftige gemeenskappe te bemagtig en aan hulle toegang te verleen tot menslike, ekonomiese en materiële hulpbronne (diakonia).

Vervolgens vereis die teologiese en kontekstuele dimensie van gemeentelike betrokkenheid 'n besondere holistiese betrokkenheid - 'n ontmoeting met die mens asook 'n ontmoeting met sy of haar konteks en omstandighede. Kotze (1997:65) noem dit'n kontemporêre holisme. So 'n holisme word duidelik in die Bybel waargeneem spesifiek ten opsigte van Jesus se aardse bediening. Nie net het dit vir Jesus gegaan om mense in die regte verhouding met God te herstel nie, maar om ook in hulle fisiese behoeftes te voorsien (vgl. Matt 8:1-4 en 14:16).

Samuel en Sudgen (1987:236) gaan selfs so ver om te sê dat 'n onderskeid tussen die geestelike en fisieke behoeftes van mense ' $n$ blatante dwaalleer is, want dit gee aanleiding tot ' $n$ onbybelse onderskeid. Nie net het die kerk as geloofsgemeenskap die taak om mense met God te versoen nie, maar die kerk het ook die taak om mense met mekaar en die omgewing of natuur te versoen. Indien gemeentes se betrokkenheid by sosiale uitdagings as 'n holistiese uitreik (geestelike én fisieke betrokkenheid) benader word, tree 'n vorm van verhoudingsbou na vore wat die vermoë het om oor grense te kan beweeg - grense soos kerk en kultuur (Shaw \& Van Engen 2003:42).

Hierdie artikel wil bogenoemde teologies-teoretiese waarhede empiries in drie Christelike gemeenskapsprojekte toets. In die eerste deel van die artikel word die teoretiese raamwerk van die navorsing beskryf en word Duane Elmer' se 'cross-cultural servanthood'-model in gesprek

1.Dr Duane Elmer dien as voorsitter van die fakulteit International Studies and Mission aan die Trinity Evangelical Divinity School naby Chicago. Sy spesialiseringsveld sluit onder meer die volgende in: internasionale teologiese opleiding, vrede en versoening, interkulturele bedienings, asook interpersoonlike verhoudingsvaardighede. Sien die amptelike webblad van die Trinity Divinity School: web.tiu.edu/ divinity/academics/faculty/Elmer (besigtig 17 Februarie 2012). 
gebring met Miroslav Volf se beeld van 'n omhelsing (Volf 1996). In die tweede deel word die belangrikste resultate van die empiriese navorsing uiteengesit.

\section{Die bevordering van ' $n$ interkulturele ontmoeting}

Duane Elmer se model tot 'cross-cultural servanthood'2 word in hierdie artikel gebruik as 'n noodsaaklike raamwerk vir die identifisering en evaluering van spesifieke prosesse by gemeentelike betrokkenheid. ${ }^{3}$ Hierdie model is reeds in meer as 20 lande suksesvol aangewend in verskeie praktykevaluerings (Elmer 2006:150) en word in die tweede onderafdeling bespreek. Ten einde die kompleksiteit van multikulturele uitreike te verstaan, word in die volgende afdeling gereflekteer oor die unieke uitdagings daaraan verbonde.

\section{Die gebrekkige uitreik na die naaste van'n ander kultuur}

Volf (1996) wys daarop dat moderne samelewings grootliks bedreig word deur die onvermoë van mense om in 'n verbond (vaste verbintenis) tot mekaar te staan. So'n verbond omskryf hy as:

$\ldots$ an indefeasible and a continuing relationship. The bond is relatively unconditional, relatively indissoluble ... The bond contemplates open-ended and diffuse obligations, implicates the whole person or group, and creates a salient status. (bl. 150)

So 'n verbond met die naaste gaan nie slegs om 'n eenheid na gelang van een of ander gemeenskaplikheid nie, maar sluit ook 'n morele verbintenis in. Hierdie morele verbintenis verbind Volf (1996:154) met identiteitsvorming, waardeur 'the very identity of each is formed through relation to others'.

'n Verbond met die naaste vra dus om 'n perspektiefverskuiwing vanaf my eksklusiewe benadering tot dié van 'n ander. Sodoende vra dit nie net om 'n verandering of plek maak in onsself vir ander nie, maar ook 'n heroorweging van ons eie identiteit in die aangesig van 'n ander.

So 'n perspektiefverskuiwing sien ons by God se menswording en kruisdood. Deur sy menswording en kruisdood, het God nie alleen deel gekry aan die menslike bestaan nie, maar het Hy ook die verhouding tussen God en die mens herstel. Volf (1996) skryf:

The new covenant is God's embrace of the humanity that keeps breaking the covenant; the social side of that new covenant is our way of embracing one another under the conditions of enmity. (bl. 156)

Hierdie behoefte aan 'n 'verbond' (soos deur Volf beskryf) word geillustreer deur die Instituut vir Geregtigheid en

2.Kruiskultureel en interkultureel word soms as sinonieme en soms juis nie as sinonieme gebruik nie. Elmer se benadering van kruiskultureel kom inhoudelik sterk ooreen met die verstaan van ' $n$ interkulturele ontmoeting, waar die klem op ' $n$ aktiewe dialoog en wederkerigheid val. Saayman $(1990 \cdot 316)$ beskryf dit vanuit ' $n$ aktiewe dialoog en wederkerigheid val. Saayman (1990:316) beskryf dit vanuit ' $n$ evangeliese oogpunt as ' $n$ proses van vennootskap en gemeenskaplikheid, waar die interaksie bydra tot $n$ wedersydse verryking van al die betrokke individue. Om
hierdie rede verkies die skrywers om eerder die term interkultureel te gebruik.

3. Hierdie model benodig inhoudelik ' $n$ interdissiplinêre benadering waardeur die sosiologiese implikasies van verhoudingsbou aan 'n meer teologiese raamwerk gemeet word (vgl. Elmer 2006:150).
Versoening $(\mathrm{IGV})^{4}$ se versoeningsbarometer vir die jaar 2009. Groot klem word geplaas op die belangrikheid van 'n godsdienstige of mediese/terapeutiese raamwerk vir die 'genesing van individuele slagoffers, die suiwering van mense (katarsis), en/of die herstel van gebroke verhoudings' (IGV 2009:4). In die praktyk is daar egter min sprake van só 'n uitreik. Aan die hand van die versoeningsbarometer ${ }^{5}$ het die IGV bevind dat in 2009 slegs 49\% van Suid-Afrikaners voel dat die verhoudings tussen die verskillende rassegroepe verbeter het, teenoor $61 \%$ in 2006 . Vertroue in 'n 'gelukkige toekoms vir alle rasse' het vanaf sy hoogste vlak, $86 \%$ in 2005, geval tot 62\% in 2009 (IGV 2009:12-14).

Resultate toon verder dat daar onder Suid-Afrikaners 'n gebrekkige interaksie tussen mense van verskillende rassegroepe in die daaglikse lewe bestaan. In 2009 het een uit vier (24\%) Suid-Afrikaners aangedui dat hulle nooit met mense van ander rasse 'on a typical day during the week, whether at work or otherwise' praat nie. Vanuit 'n versoeningsoogpunt, is dit duidelik dat groter erns gemaak sal moet word met versoening in die bevordering van 'n ware interkulturele ontmoeting. Veral die feit dat gemiddelde minder as die helfte van Suid-Afrikaners met mense van verskillende histories-gedefinieerde oriëntasie per dag praat, verg aandag.

Sodanige beperkte uitreik na die naaste kan waarskynlik toegeskryf word aan 'n gebrek aan nederigheid in die ontmoeting met die sogenaamde ander. Elmer (2006:17) wys daarop dat ' $n$ gesindheid van meerderwaardigheid een van die grootste uitdagings by ' $n$ missionêre betrokkenheid in die breër kulturele samelewing is. Dit tree op die volgende wyses na vore:

- 'I need to correct their error (meaning I have superior knowledge).'

- 'My education has equipped me to know what is best for you (so let me do most of the talking while you do most of the listening and changing).'

- 'I am here to help you (so do as I say).'

- 'I can be you spiritual mentor (so I am your role model).'

- 'Let me disciple you, equip you, train you (often perceived as "let me make you into a clone of myself")'.

Hierdie meerderwaardige gesindheid in die ontmoeting met die naaste verskil skerp van God se missionêre betrokkenheid in die lewe van die mens. Nêrens word Jesus se nederigheid ter wille van diakonia beter uitgebeeld as wanneer Hy sy dissipels se voete was nie (Joh 13).

4.Die IGV realiseer sy visie, 'Building fair, democratic and inclusive societies in Africa', deur die volgende areas van aktiwiteite:

- Navorsing en' $n$ evaluering van ekonomiese, sosiale en politieke tendense. - Die bevordering van versoening en herstel in post-konflik gemeenskappe. - Die verskaffing van onderrighulpbronne in die bevordering van versoening.

- Publieke dialoog en politieke ingryping vir die vestiging van inklusiewe samelewings.

Kyk ook die webblad: http://www.ijr.org.za/about-us.php (besigtig 08 Desember 2010).

5. Hierdie versoeningsbarometer berus op ' $n$ ondersoek deur die IGV in 2003 , aangaande die faktore wat onder die Suid-Afrikaanse publiek die grootste invloed uitoefen in die bevordering van versoening, naamlik menslike sekuriteit, die heersende politieke bestel, politieke relasies oor grense heen, dialoog, historiese konfrontasie en rasseverhoudings. Jaarliks word hierdie faktore aan die hand van die konfrontasie en rasseverhoudings. Jaarliks word hierdie faktore aan die hand van die
volgende hipotese getoets: 'It is hypothesised that when the indicators strengthen or improve, reconciliation is likely to be advanced' (IGV 2009:5). 
Alhoewel so 'n nederigheid, vanuit 'n Christelike oogpunt, dalk na 'n minsame of bevorderbare deug vir die lewe en getuienistaak van gelowiges mag klink, is daar 'n belangrike uitsondering. In Kolossense 2:18-23 waarsku Paulus die gelowiges om teen 'n selfsugtige vorm van nederigheid te waak. Elmer (2006:29) beskryf dit as 'n 'showy, conspicuous humility', gerig op groter aansien. Hierteenoor gaan 'n ware uitreik nie om 'n gebaar van nederige diens nie, maar eerder om 'n leefstyl van nederige diens. So 'n leefstyl getuig ten diepste van 'n gesindheid waar 'die een die ander hoër ag as homself' (Fil 2:3).

\section{Verhoudingsbou in 'n multikulturele konteks}

In die volgende ses afdelings sal daar in groter diepte op Duane Elmer se 'cross-cultural model' (2006) gereflekteer word. Inhoudelik sluit hierdie model sterk aan by Miroslav Volf se beeld van 'n omhelsing en daarom sal Volf deurgaans tot die gesprek betrek word. Volgens Volf (1996:140) het sy omhelsing nie alleen betrekking op menseverhoudings nie, maar ook op 'n versoening tussen mense onderling. 'n Interkulturele ontmoeting word dus ten beste deur die volgende bevorder.

\section{Openheid en gasvryheid}

Openheid en gasvryheid het ten diepste betrekking op die vermoë om ander mense in jou teenwoordigheid te verwelkom en veilig te laat voel. So 'n openheid vind ons in Lukas 15:2, waar Jesus saam met die sondaars, veragtes en verwerptes van die samelewing geëet het en hulle onvoorwaardelik aanvaar het.

Vir die aanneem van so 'n 'countercultural' openheid, onderskei Elmer (2006:39-40) tussen drie belangrike vereistes:

1. In die eerste plek vra openheid om 'n besondere vermoë (aanleg) wat ingeoefen en verbeter moet word.

2. In die tweede plek is openheid op mense gerig - mense soos ons, maar ook mense anders as ons.

3. In die derde plek moet openheid op 'n kultureel aanvaarbare wyse tot uitdrukking kom, sodat andere welkom en veilig kan voel in ons teenwoordigheid.

Volf (1996) vat bogenoemde drie kenmerke van openheid saam deur te praat van 'n 'embrace.' Embrace beskryf hy as:

The will to give ourselves to others and 'welcome' them, to readjust our identities to make space for them, is prior to any judgment about others, except that of identifying with them in their humanity. (bl. 29)

In die Bybel vind ons talle oproepe tot openheid, veral in die vorm van gasvryheid (vgl. Rom 12:13; 16:23; Tit 1:8; 1 Pet 4:9; 3 Joh 6). Sodanige gasvryheid is volgens Keifert (1992:58) kenmerkend van God se selfopofferende, bevrydende teenwoordigheid en vra van ons om ook hierdie gesindheid te openbaar.

Aan die hand van 'n ondersoek van Malcolm Gladwell, wys Elmer (2006:48) daarop dat die gemiddelde persoon tussen 2.4 en 4.6 sekondes neem om te besluit of hulle in 'n verbintenis met ' $n$ ander persoon wil staan of nie. So 'n besluit word meestal vanuit ' $n$ visuele waarneming gemaak. Erger nog, daar word maklik positiewe of negatiewe oordele bygevoeg (Elmer 2006:49). Sulke stereotiperings skaad nie net die openheid nie, maar veroorsaak ook dat ons onsself van andere afsluit.

Vanuit 'n openheidsoogpunt, is dit dus noodsaaklik om 'n meer inklusiewe benadering ten opsigte van kulturele verskille te bewerkstellig. Aan die hand van die beeld van 'n omhelsing, skryf Volf (1996:141) dat die oopmaak van die arms vra vir 'n opregte begeerte na die ander, 'n aflegging van my eie 'self-enclosed' identiteit, sodat die ander deel van my lewe kan word. Deur waarlik oop te wees vir andere, ontstaan nie net 'n uitnodiging nie, maar ook 'n geleentheid om mense ten spyte van verskille te aanvaar.

\section{Aanvaarding}

Aanvaarding het ten diepste betrekking op die erkenning en kommunikering van die selfwaarde of menswaardigheid van 'n ander persoon. So 'n aanvaarding kan sterk met Paulus se opdrag in Romeine 15:7 verbind word: 'Aanvaar mekaar dan, soos Christus julle ook aanvaar het, tot eer van God.'

Vir Elmer (2006:58) het aanvaarding op drie belangrike funksies betrekking:

1. Eerstens is dit 'n erkenning dat God ons onvoorwaardelik aanvaar.

2. Tweedens vra dit van ons om ook andere onvoorwaardelik te aanvaar.

3. Derdens gaan 'n aanvaarding van andere ten nouste saam met die verering van God.

Hierdie drie aanvaardingsfunksies word sterk beliggaam deur Volf (1996:143) se beeld van die toemaak van die arms by 'n omhelsing. Hy wys daarop dat so 'n omhelsing 'n wederkerigheid vra wat uitloop op 'n wedersydse gee en neem asook 'n 'soft touch'. By 'n 'soft touch' gaan dit nie so seer om iemand vanuit die 'eie-raamwerk' te verstaan nie, maar eerder 'the-ability-not-to-understand'. Volf (1996:144) wys daarop dat 'without the ability-not-to-understand a genuine embrace is impossible'.

Aanvaarding vereis dus 'n kommunikering van respek en menswaardigheid teenoor die ander, selfs al verstaan ons hom of haar nie of stem ons nie met hom of haar saam nie. Aanvaarding kan dus verstaan word as ' $n$ gesindheid van onvoorwaardelike liefde sonder veroordeling. Die 'ander' hoef nie soos 'ons' te word of soos 'ons' te maak nie. Daardeur erken ons dat alle mense na God se beeld geskape is en dat die wyse waarop ons met die naaste omgaan ook belangrike implikasies vir ons verhouding met God inhou. Elmer (2006) skryf:

If I extend to them hospitality, I reveal God's beauty and grace. If I am uncharitable toward another person, I fail to honor the God who gave them dignity. Jesus's identification with us is so intense that whatever touches us touches him. (bl. 44) 
Deur die ander met onvoorwaardelike liefde te aanvaar, word nie net nader aan mekaar beweeg nie, maar word 'n vertrouensverhouding ook moontlik.

\section{Vertroue}

Verhoudings floreer waar vertroue bewerkstellig word. Vertroue impliseer ten diepste 'n verantwoordelikheid vir andere en 'n optrede in hulle belang. Elmer (2006:77-78) lig vier belangrike vereistes in die bevordering van vertroue uit:

1. In die eerste plek word vertroue alleen oor tyd bewerkstellig. Elmer (2006:77) beskryf dit as 'small incremental steps over time'. Deur gedeelde ervarings tree mense in dieper verhoudings tot mekaar. 'n Goeie vertrekpunt lê byvoorbeeld in die aanleer van die taal van die ander.

2. In die tweede plek vereis vertroue risiko's, meestal emosioneel van aard. Botsings is onvermydelik, maar waar misverstande opgeklaar word en foute erken word, word vertroue aansienlik versterk (Elmer 2006:77).

3. In die derde plek eis vertroue 'n perspektiefverskuiwing vanaf my perspektief na dié van die ander (Elmer 2006:77). Mense ervaar nie noodwendig vertroue op dieselfde wyse nie. Goeie mensekennis is dus onontbeerlik.

4. In die vierde plek moet vertroue gekoester word. Die Triniteit is die mees ideale model vir verbintenisse. Nie net staan die drie persone van die Godheid in 'n volkome eenheid nie, maar hulle tree ook dienooreenkomstig op (Elmer 2006:78).

Batista (1995:248) wys daarop dat die sendingopdrag van God aan sy kinders spesifiek om 'n helende en versorgende dimensie van die evangelie gaan. Hy skryf: 'Mission is nurtured by a deep pastoral concern on how to reconstruct communities in our societies.'

Vir Volf (1996:100) is die bevordering van vertroue vir die herstel van gebroke verhoudings in die samelewing onderhewig aan vier belangrike of noodsaaklike gebeurtenisse, naamlik 'repentance', 'forgiveness', 'making space in oneself for the other' en 'healing of memory'. ${ }^{6}$

Dit is egter belangrik om te besef dat waar vertroue bevorder word, dit op verskillende wyses in verskillende kulture na vore tree. Spesifieke handelings wat van vertroue in een kultuur getuig, kan baie maklik in 'n ander een skade aanrig. 'n Persoon wat byvoorbeeld laat vir 'n afspraak opdaag in 'n Westerse konteks, sal maklik as onbetroubaar beskou word. Hierteenoor sal sulke gedrag vanuit 'n Afrika-konteks as normaal beskou word, omdat mense dikwels ver afstande te voet moet aflê (Elmer 2006:81-82).

Dit is dus belangrik om te weet watter optredes vertroue bevorder en watter dit benadeel. Egte vertroue vereis 'n gewilligheid om te leer.

\section{Gewilligheid om te leer}

Waar daar nie ' $n$ sensitiwiteit bestaan vir die mense na wie uitgereik word en hulle leef- en werkswyse nie, kan bepaalde

6.Vir'n meer breedvoerige bespreking, vergelyk Volf (1996:113-139) vorms van kennis maklik as 'n arrogante en onsensitiewe gesindheid ervaar word. Elmer (2006:92) wys daarop dat die sogenaamde 'telling approach' baie negatiewe uitwerkings in die vroeë sending gehad het.

Met sy beeld van 'n omhelsing wys Volf (1996:143-144) daarop dat, nadat die arms vir 'n omhelsing oopgemaak word, daar vir die ander gewag moet word om nader te kom. So 'n nederige wag, vra van ons om meer van die ander te leer en om hom of haar waarlik te ontmoet. Dit noem Elmer (2006:93) 'nederige lering' - die vermoë om belangrike inligting oor, van en saam met ander te leer.

Leer oor ander: Wanneer 'n nuwe kultuur betree word, is dit nodig om meer oor die mense van daardie kultuur te leer. Hiervoor kan verskeie hulpbronne aangewend word. Ons kan byvoorbeeld meer oor die kultuur lees of selfs met mense gesels wat met sodanige kultuur vertroud is. ' $n$ Groot gevaar wanneer oor ander geleer word, is egter die siening dat insig in ander mense binne ons verstaansvermoë is (Elmer 2006:94-95). Daar kan maklik gedink word dat ons genoeg oor andere weet om daarom tot hulle beste voordeel op te tree. Die uiteinde van so ' $n$ ingesteldheid is 'n roekelose objektivering, waardeur ons hulle met ons wysheid, teenwoordigheid, antwoorde en hulpbronne probeer bedien. Net so lei dit maklik tot 'n stereotipering wanneer ons dink dat ons andere vanuit verskeie veralgemenings ken.

Dit is nodig om nie net oor andere te leer nie, maar om ook van hulle te leer om daardeur verhoudings te bevorder.

Leer van ander: Om van andere te leer word van groter waarde beskou as die leer oor ander. Waar moeite gedoen word om van ander te leer, word stereotiperings, vooroordele en rassisme skerp belig en uitgedaag (Elmer 2006:98). Kommunikasie is hier baie belangrik.

By kommunikasie gaan dit nie alleen om 'n poging om die idees en gedagtes van andere te leer ken nie, maar ook om dit te verstaan. Elmer (2006:99) wys op die belangrikheid van dialoog, vriendskap en solidariteit as deel van 'n lewenslange leerproses. Dit bring ons by die derde leerproses.

Leer saam met ander: Om saam met ander te leer, is 'n redelik onbekende fenomeen. Elmer (2006:103) beskryf dit as ' $\mathrm{n}$ leerproses wat plaasvind 'in relationship, in mutuality, in partnership where neither side is above or beneath'. Waar sodanige leer plaasvind, vind interaksie met respek plaas. Dit het wedersydse verryking tot gevolg.

Situasies waarbinne verkeerde of foutiewe opvattings bestaan, moet egter met versigtigheid benader word (Elmer 2006:114). Dit gaan nie in die eerste plek daarom om te doen wat reg is volgens ons eie kultuur nie, maar om kennis vanaf die plaaslike mense te verkry - om van hulle te leer, om hulle kulturele waardes te verstaan en hulle binne hul kultuur te ondersteun. By so 'n leerproses is daar nie ruimte vir 'n 'onshulle'-onderskeid nie, maar dit gaan eerder om 'n solidariteit in die vorm van 'ons'. Waar so'n solidariteit tot stand gebring word, baan dit die weg tot opregte verstaan. 


\section{Opregte verstaan}

Waar mense nie mekaar verstaan nie, sal gedrag maklik as vreemd ervaar word en sal dit die beoogde verhoudings nadelig beïnvloed. Alhoewel so 'n verstaan in die meeste gevalle tyd neem, is dit belangrik om dit ook te bevorder selfs waar die blootstelling van korte duur is.

Elmer (2006:126) skryf: 'It's hard to understand why people do what they do. Until we understand, it will be difficult to effectively communicate or to develop any meaningful relationships.'

Hierdie verstaan van die ander word op 'n besondere wyse vergestalt deur die losmaak van die arms na afloop van Volf se beeld van 'n omhelsing. Hy wys daarop dat 'n omhelsing nie ten doel het om 'two bodies one' te maak nie (Volf 1996:144). Veel eerder gaan dit by 'n omhelsing om mekaar te verstaan vanuit die bevordering van wedersydse respek. 'n Verstaan van die ander kan beslis nie net deur 'n enkele (eenmalige) omhelsing bewerkstellig word nie, maar verdere omhelsings word benodig. Volf (1996:145) skryf: 'The end of an embrace is, in a sense, already a beginning of an embrace.'

By'n opregte verstaan gaan dit dus om 'n ware kennismaking met die ander. Elmer (2006:136) beskryf dit as die ontwikkeling van 'n 'double vision': '... seeing the world through your own cultural lenses and also being able to see more and more clearly through the lenses of another culture'. Waar so 'n interaksie tussen individue bevorder word, baan dit nie net die weg tot 'n naderbeweeg aan mekaar nie, maar ook 'n meer effektiewe behoefte-identifisering, beplanning, implementering, bestuur en evaluering van 'n sosiale betrokkenheid (Schenk \& Louw 1995:189).

'n Opregte verstaan van mekaar en elkander se omstandighede, leer ons om in mekaar se blydskap, hartseer en lyding te deel. 'n Opregte verstaan help daarom om mekaar meer effektief te bedien.

\section{Diensbaarheid}

Elmer (2006:145) wys daarop dat naastediens impliseer om die naaste as ons gelyke te erken. Die proses van 'n interkulturele ontmoeting op die vlak van verhoudingsbou dan dus ook as diens beskryf word.

\section{Volf (1996:146-147) skryf soortgelyk:}

The equality and reciprocity that are the heart of embrace can be reached only through self-sacrifice (Mark 10:41-45), even if selfsacrifice is not a positive good, but a necessary via dolorosa in a world of enmity and indifference toward the joy of reciprocal embrace.

In die lig van Jesus se onbaatsugtige aardse bediening, definieer Elmer (2006:146) diens as 'the ability to relate to people in such a way that their dignity as human beings is affirmed and they are more empowered to live God-glorifying lives'. Die bediening van die naaste, vanuit 'n Christelike oogpunt, is dus baie meer as die voorsiening in een of ander nood of behoefte. Elmer (2006:148) skryf dat die beste bediening van die naaste na vore tree vanuit verhoudingsbou met die naaste en dat dit selfs die maak van foute insluit.

Alhoewel Christelike diens nie gemeet kan word in terme van iets wat vir of aan iemand gedoen word nie, is daar wel een onveranderlike uitkoms in die bediening van die naaste. Volf (1996:147) wys daarop dat ' $n$ ware omhelsing nie een of albei partye onveranderd kan laat nie. Christelike diens behoort gevolglik nie gemeet te word in terme van wat vir ' $n$ ander gedoen word nie, maar veel eerder in terme van die verhoudings wat oor grense heen bewerkstellig word.

\section{Samevatting}

Vir die evaluering van interkulturele ontmoetings en gemeentelike sosiale betrokkenheid is Elmer se model van diensskap van groot waarde. Omdat gemeentelike sosiale betrokkenheid by nood veel eerder om die bevordering van verhoudingsbou behoort te gaan as om blote dienslewering, stel Elmer (2006:150-151) voor dat sy model eintlik van agter na voor benader moet word:

- Diens. 'n Mens kan beswaarlik 'n ander bedien indien jy hom of haar nie verstaan nie. Net so kan versoening ook nie tot stand gebring word sonder ' $n$ ontmoeting tussen die oortreder en die lydende party vir die verstaan van die omvang van 'n oortreding nie. Sonder die nodige verstaan, sal diens en/of versoening geforseerd en onopreg wees (Elmer 2006:150).

- Verstaan. 'n Mens kan nie 'n ander verstaan indien jy nie bereid is om van hom of haar te leer nie. Uiteindelik behoort daar saam geleer te word. Vir Elmer (2006:151) getuig 'n leerbare gesindheid van nederigheid en 'n gewilligheid om met ander te identifiseer.

- Leer. Dit is baie moeilik om van ander te leer indien daar nie 'n vertrouensverhouding

bestaan nie. Mense sal beswaarlik belangrike inligting met iemand deel wat hulle nie

vertrou nie, veral nie in 'n multikulturele konteks nie (Elmer 2006:151).

- Vertroue. Vertroue kan nie bevorder word indien daar nie aanvaarding is nie. Wanneer ander aanvoel dat jy hulle as waardige medemense waardeer, word vertroue moontlik (Elmer 2006:151).

- Aanvaarding. Dit is onmoontlik om ander te waardeer en te aanvaar indien hulle nie in jou teenwoordigheid welkom en veilig voel nie (Elmer 2006:151). Ten diepste vereis dit'n openheid teenoor die ander.

- Openheid. Openheid verg van diegene in 'n ander kulturele raamwerk om uit hulle gemaksones te beweeg en volhoubare verbintenisse tot stand te bring in 'n konteks van kulturele verskille (Elmer 2006:151). In wese gaan dit hier om menswaardigheid, om elke persoon, ondanks verskille, as 'n beelddraer van God te sien.

Hierdie ses elemente van ' $n$ interkulturele ontmoeting, is verder aan die hand van navorsing (Ries 2012:106) vir die volgende getoets:

1. die onderskeiding van die prosesse en strukture van 'n interkulturele ontmoeting by Christelike gemeenskapsprojekte 
2. ' $n$ evaluering van die transformasievlak van verhoudings sodat prosesse of strukture tot stand gebring kan word.

\section{'n Empiriese studie van drie interkulturele ontmoetings}

As deel van 'n empiriese studie is die interkulturele ontmoeting by drie Christelike gemeenskapsprojekte geëvalueer (Ries 2012:106). Die drie gemeenskapsprojekte wat ondersoek is, was Shiloh Synergy, Sarfat Community Projects en die Elsiesrivier Care Centre. Al drie gemeenskapsprojekte maak gebruik van 'n Christelike raamwerk vir betrokkenheid en is werksaam in die informele nedersettings van Wallacedene, Bloekombos en Klipheuwel, asook die woonbuurt van Leonsdale in Elsiesrivier.

Om te bepaal op watter wyse hierdie projekte tot 'n interkulturele ontmoeting bydra, was dit belangrik dat hierdie projekte reeds vir 'n redelike tyd aktief of werksaam moes wees. Vyf jaar is geneem as 'n aanduiding van 'n redelik vlak van betrokkenheid en al drie gemeenskapsprojekte het aan hierdie kriterium voldoen (Ries 2012:16-17).

Dit was verder noodsaaklik om diegene wat vanuit 'n gemeentelike konteks by die onderskeie gemeenskapsprojekte betrokke is (die veranderingsagente) asook diegene wat deur die onderskeie programme bedien of gehelp word (die bemagtigdes), te betrek. Vraelyste sowel as onderhoude is in die ondersoek gebruik ${ }^{7}$ (Ries 2012:114).

Deur middel van vraelyste is die kwaliteit van die interkulturele ontmoeting tussen die veranderingsagente en die bemagtigdes gëevalueer (in terme van die ses elemente van 'n interkulturele ontmoeting), terwyl die onderhoude weer groter insig verskaf het aangaande die verhoudingsbou wat deur die gemeenskapsprojekte tot stand gekom het (in terme van die bevordering van sosiale transformasie).

Aangesien die navorsing op persoonlike verbintenisse en verhoudings binne ' $n$ interkulturele raamwerk fokus, het die betrokkenheid oor tyd die vernaamste kriterium gevorm waarvolgens die onderskeie proefpersone geïdentifiseer is.

Wat die veranderingsagente betref, was die gemiddelde betrokkenheid $^{8} 8.5$ jaar, die langste betrokkenheid was 24 jaar en die kortste 4 jaar. Drie van die proefpersone was langer as 10 jaar, vyf langer as 5 jaar, vier 5 jaar en drie 4 jaar betrokke (Ries 2012:138).

Wat die bemagtigdes betref, was die gemiddelde betrokkenheid 7.8 jaar, die langste betrokkenheid was 15 jaar en die kortste 3 jaar. Vyf van die proefpersone was 10 jaar en langer betrokke, vyf langer as 5 jaar, een 5 jaar, een 4 jaar en drie 3 jaar betrokke (Ries 2012:140).

7.'n Volledige uiteensetting van die metodologie asook die metode wat gebruik is om die gevallestudie te ondersoek, is in Ries (2012:106-121) verskaf. Die vrae vir die die gevallestudiete ondersoek is in (2012.200-212) en die vrae vir die onderhoude is in

8. Hierdie betrokkenheid is nie slegs ' $n$ aanduiding van die betrokkenheid by die gemeenskapsprojek as organisasie nie, maar ook die betrokkenheid in die gemeenskap wat deur die onderskeie gemeenskapsprojekte bedien word.
Ten opsigte van die geloofstatus van die proefpersone, het almal aangedui dat hulle gelowig is en dat hulle die Christelike geloof as geloofstradisie bely (Ries 2012:139, 141).

\section{Vraelyste}

Vraelyste is deur sowel die veranderingsagente as die bemagtigdes ingevul om die kwaliteit van die interkulturele ontmoeting te bepaal. Uit die terugvoer het konstruktiewe replikasie en saturasie duidelik geblyk (Ries 2012:148). Die replikasie of ooreenkomste het getoon dat die verskillende proefpersone'n definitiewe bewustheid van die problematiek en komplekse aard van ' $n$ interkulturele ontmoeting by gemeenskapsbetrokkenheid openbaar (Ries 2012:165). Die vraelyste wou in die eerste plek die interkulturele ontmoeting evalueer soos dit tussen die veranderingsagente en die bemagtigdes van die drie gemeenskapsprojekte tot stand kom. ' $n$ Uiters positiewe benadering van die interkulturele ontmoeting is waargeneem.

Aan die hand van Elmer se sesvoudige model van 'n interkulturele ontmoeting, word 'n kernopsomming van die vraelyste se empiriese data verskaf en word dit uiteengesit volgens die terugvoer vanaf die veranderingsagente en bemagtigdes (Ries 2012:147-149).

\section{Openheid en gasvryheid}

Veranderingsagente: In terme van die bevordering van 'n openheid, het die meerderheid veranderingsagente aangetoon hoe belangrik ' $n$ doelbewuste samesyn is met diegene na wie uitgereik word. In die tweede plek is die belangrikheid van' $n$ persoonlike ontwikkeling in die persoon self (die veranderingsagent) uitgelig. So 'n ontwikkeling is positief met die aanleer van spesifieke vaardighede verbind, byvoorbeeld luister- en beradingsvaardighede.

Bemagtigdes: Op soortgelyke wyse het die meerderheid bemagtigdes aangetoon hoe belangrik 'n doelbewuste samesyn is. Vir hulle is so 'n samesyn die beste bewerkstellig waar dit met 'n geloofs- of godsdienstige onderbou gepaard gegaan het. In die tweede plek het hulle gevoel dat daar nader aan mekaar beweeg is omdat hulle nie as passiewe agente gehanteer is nie, maar doelbewus betrek is om self diensbaar te wees. In die derde plek het hulle op die liefde, vriendelikheid en omgee gewys wat hulle vanuit die interaksie ervaar het.

\section{Aanvaarding}

Veranderingsagente: In die bewerkstelliging van aanvaarding, het die meerderheid veranderingsagente aangetoon dat agendas, stereotipes en vooroordele van die grootste uitdagings is by die uitreik na 'n ander gemeenskap. Tweedens is 'n gevoel van wantroue beskryf, en derdens die struikelblok van taalverskille.

Bemagtigdes: Die meerderheid bemagtigdes het aangetoon dat die afstand wat maklik na vore tree by 'n gemeenskapsgebaseerde uitreik (bv. uitdagings soos agendas 
en stereotipes), na hulle mening, die beste hanteer is wanneer ' $n$ besondere band of verbintenis tot stand gebring is. Hulle het dit as ' $n$ 'familie-gevoel' beskryf.

\section{Vertroue}

Veranderingsagente: Die meerderheid veranderingsagente het daarop gewys dat hulle gevoel het dat hulle onderlinge vertroue die beste bevorder het deur hulle Christenskap uit te leef, hetsy deur doelbewuste geestelike byeenkomste of deur hulle eie Christelike voorbeeld. Aansluitend hierby het hulle gemeen dat die betrokkenheid oor 'n wesenlike tydsverloop 'n groot verskil in die bevordering van vertroue gemaak het.

Bemagtigdes: Al die bemagtigdes het daarop gewys dat hulle die verteenwoordigde gemeenskapsprojek vertrou en dat hierdie vertroue spesifiek bevorder is wanneer hulle 'n opregte besorgdheid vir die gemeenskap ervaar het en wanneer die uitreik op 'n eerlike en deursigtige wyse na vore getree het.

\section{Gewilligheid om te leer}

Veranderingsagente: Die veranderingagente het daarop gewys dat dit noodsaaklik is om diegene na wie uitgereik word beter te leer ken, en dat so 'n lering geskied langs die weg van 'n opregte sensitiwiteit en belangstelling in diegene na wie uitgereik word. Net soos by vertroue, het hulle ervaar dat egte lering alleen bevorder kan word waar die betrokkenheid oor ' $n$ wesenlike tydsverloop geskied.

Bemagtigdes: Al die bemagtigdes het gewys op die belangrikheid om by mekaar te leer - diegene wat uitreik en diegene na wie uitgereik word. Volgens hulle het so 'n gesamentlike leer die beste na vore getree indien dit saamgeval het met spesifieke sosialiseringsgeleenthede (bo en behalwe die projek). Hulle het ook aangevoer dat sodanige leer van mekaar effektief deur gesamentlike Christelike byeenkomste beliggaam is en ook daar waar daar ' $n$ belangstelling in mekaar vanuit die verskillende projekte ervaar is.

\section{Opregte verstaan}

Veranderingsagente: Die meerderheid veranderingsagente het ervaar dat hulle betrokkenheid (in die vorm van spesifieke projekte) hulle siening van diegene na wie uitgereik word, op 'n positiewe wyse verander het. Die oorgrote meerderheid het getuig dat hulle diegene na wie uitgereik word, beter leer verstaan het en dat 'n besondere vorm van empatie vir hulle tot stand gekom het.

Bemagtigdes: Al die bemagtigdes het ervaar dat die betrokkenheid by spesifieke projekte hulle siening van diegene wat na hulle gemeenskap uitreik, in 'n positiewe rigting laat verander het. Almal het verder aangedui dat hulle verstaan wat die verteenwoordigde gemeenskapsprojek in hulle gemeenskap wil bereik. In die eerste plek is ' $n$ begeerte om die gemeenskap te verbeter genoem, in die tweede plek 'n besorgdheid oor kinders en gelyk daarmee die geestelike bearbeiding van die gemeenskap.

\section{Diensbaarheid}

Veranderingsagente: Die meerderheid veranderingsagente het aangetoon dat die bevordering van mense se menswaardigheid en die aandag aan hulle emosies en selfontwikkeling die meeste tydens gemeenskapsbetrokkenheid ontbreek, en daarom groter aandag verdien. Tweedens is die belangrikheid van die bevordering van ' $n$ verhouding met God (as 'n evangeliseringstaak) uitgelig.

Bemagtigdes: Die meerderheid bemagtigdes ervaar dat die grootste waarde wat die verteenwoordigde gemeenskapsprojek in hulle lewens toegevoeg het, die bevordering van hulle selfvertroue en ' $n$ innerlike genesing was. Groot klem is geplaas op die bemagtiging om die gemeenskap te gaan verbeter. In die tweede plek is 'n besondere geestelike groei of ondersteuning uitgelig, en in die derde plek die waarde van opregte vriendskap.

Die feit dat die terugvoer van die vraelyste ${ }^{9}$ (van die veranderingsagente sowel as die bemagtigdes) in 'n groot mate by mekaar aangesluit het, wys daarop dat 'n ware interkulturele ontmoeting tussen hierdie drie Christelike gemeenskapsprojekte tot sy reg gekom het. Die betrokkenheid oor tyd, die opregte belangstelling in mekaar, asook die Christelike raamwerk van die onderskeie projekte, het 'n wesenlike verskil gemaak.

\section{Onderhoude}

Ter aanvulling van hierdie positiewe antwoord op die ervaring van die interkulturele ontmoeting by gemeenskapsprojekte, was dit nodig om verder ondersoek in te stel aangaande die interkulturele ontmoeting en te bepaal of die betrokkenheid by die onderskeie Christelike gemeenskapsprojekte tot 'n sosiale transformasie gelei het. Sodanige transformasie is deur semi-gestruktureerde onderhoude ${ }^{10}$ gemeet in terme van die volgende uitkomste:

1. 'n meer spontane of opregte besorgdheid oor die behoeftes van die naaste asook 'n geloofsverryking (motivering vir betrokkenheid)

2. 'n vorm van diens of betrokkenheid wat op die totale mens gerig is (omvang van betrokkenheid)

3. 'n meer volhoubare betrokkenheid (standhoudende ondersteuning).

In terme van die eerste uitkoms, naamlik dat 'n meer spontaneof opregte besorgdheid tot stand kom, het die onderhoude met veranderingsagente aangetoon dat die betrokkenheid sterk gemotiveer was deur 'n roeping van God en die passie of bevrediging om te kan help (Ries 2012:150). Op soortgelyke wyse het die meerderheid bemagtigdes daarop gewys dat hulle betrokkenheid die gevolg was van geestelike bearbeiding of evangelisering en die begeerte om 'n verskil in hulle eie gemeenskap te gaan maak (Ries 2012:154-155).

$9 . V i r$ 'n meer volledige uiteensetting van die terugvoer van die vraelyste, vergelyk Ries (2012:224-246).

10.Vir'n meer volledige uiteensetting van die terugvoer van die onderhoude, vergelyk Ries (2012:248-266). 
Bogenoemde het die navorser tot die volgende gevolgtrekking gelei:

Christelike betrokkenheid in ' $n$ ander kulturele konteks vereis ' $n$ definitiewe morele of spirituele oortuiging in die bevordering van diensbaarheid (aan die kant van diegene wat betrokke wil raak) en die vestiging van 'n gemeenskap van omgee (Ries 2012:166).

Ten opsigte van die tweede uitkoms, naamlik dat ' $n$ Christelike betrokkenheid tot 'n hoër vlak van betrokkenheid bydra, is aangetoon dat die invloed van geloof nie in die betrokkenheid oorgesien mag word nie. Vir die veranderingsagente behoort die holistiese evangeliseringstaak die mees sentrale plek by enige vorm van Christelike diens in te neem (Ries 2012:151). Eweneens wys die bemagtigdes daarop dat die Christelike gemeenskapsprojekte tot 'n definitiewe versterking van hulle geloof bygedra het en hulle tot diens aangespoor het (Ries 2012:155).

Dit het die navorser tot die volgende gevolgtrekking gelei:

Christelike betrokkenheid in ' $n$ ander kulturele konteks vereis die doelbewuste implementering van geestelike byeenkomste, wat inhoudelik ook as evangelisering vertolk kan word. Dit behoort die ware vertrekpunt of motivering vir alle betrokkenheid te wees (Ries 2012:166).

Ook in terme van die tweede uitkoms, naamlik dat Christelike betrokkenheid tot 'n hoër vlak van betrokkenheid bydra, is ontdek dat verhoudingsbou doelbewus nagestreef moet word. Vir die veranderingsagente was projekte eintlik 'n sekondêre faktor en val die klem veel eerder op verhoudingsbou en die bevordering van menswaardigheid en die bemagtiging van individue (Ries 2012:151-152). Die bemagtigdes het ook gevoel dat die Christelike betrokkenheid, in die eerste plek om 'n opregte belangstelling in die individu behoort te gaan, en dat dit van hulle vra om self ook verantwoordelikheid te aanvaar (Ries 2012:156).

Dit het die navorser tot die volgende gevolgtrekking gelei:

Christelike betrokkenheid in 'n ander kulturele konteks behoort te gaan om die bevordering van verhoudings tussen diegene wat uitreik en diegene na wie uitgereik word. In hierdie verband is die bevordering en/of implementering van projekte gerig op die vestiging van egte menswaardigheid (Ries 2012:166).

In terme van die derde uitkoms, naamlik dat 'n meer volhoubare betrokkenheid vanuit die Christelike betrokkenheid tot stand kom, is ontdek dat benewens die persoonlike motiverings om betrokke te bly, meer aandag gegee kan word aan die gemeentelike ondersteuning van diegene wat uitreik (Ries 2012:167). Die veranderingsagente was grootliks verdeeld ten opsigte van die ondersteuning wat hulle vanuit hulle tuisgemeente ontvang. 'n Gelyke aantal veranderingsagente het aangetoon dat hulle fisiek of materieel ondersteun word, terwyl ander glad nie ondersteun word nie en/of onseker is oor die ondersteuning (Ries 2012:153).
Dit het die navorser tot die volgende gevolgtrekking gelei:

Christelike betrokkenheid in ' $n$ ander kulturele konteks vra om die doelbewuste ondersteuning van diegene wat uitreik, bo en behalwe die fisieke of materiële ondersteuning van die projek. Diegene wat uitreik, gee juis 'arms en bene' aan 'n gemeente se getuienistaak en behoort daarom deur die gemeente materieel en geestelik ondersteun te word (Ries 2012:167).

Ten opsigte van die derde uitkoms, naamlik dat 'n meer volhoubare betrokkenheid vanuit die Christelike betrokkenheid tot stand kom, het die veranderingsagente ook aangetoon dat daar 'n groot geleentheid vir gemeentes bestaan om op 'n fisieke of konkrete vlak betrokke te raak. Saam met die aanleer van vaardighede is die skep van spontane (nie-bedreigende) blootstellingsgeleenthede en 'n geestelike versorging van die projek (intersessie) uitgelig (Ries 2012:153). Op soortgelyke wyse het die bemagtigdes op die belangrikheid van Christelike getuienis (evangelisasie) gewys asook hulle fisieke teenwoordigheid (Ries 2012:157).

Dit het die navorser tot die volgende gevolgtrekking gelei:

Christelike betrokkenheid in 'n ander kulturele konteks vereis fisieke teenwoordigheid waar dit nie primêr om 'n projekgedrewe oriëntering gaan nie, maar eerder die skep van nie-bedreigende blootstellingsgeleenthede en evangelisasie (Ries 2012:167).

\section{Gevolgtrekking}

Daar is tans ' $n$ debat aan die gang of geloofsgroepe wel effektiewe diensverskaffers in die samelewing kan wees. Goldsmith (2002:121) wys byvoorbeeld daarop dat daar al hoe meer besef word dat 'n holistiese uitreik noodsaaklik is, waardeur aan die fisieke en geestelike behoeftes van die mens in ' $n$ gesonde relasie aandag gegee word. Dit benodig 'n vorm van verhoudingsbou oor kulturele grense heen, waar veranderingsagente en bemagtigdes in ' $n$ dinamiese relasie gebring word om mekaar wedersyds te bedien.

Vir die evaluering van so 'n interkulturele ontmoeting, is Elmer se model van Christelike diensskap van groot waarde. Die belangrikheid van verhoudingsbou tesame met 'n Christelike uitreik in 'n ander kultuur, is ook sterk vanuit die navorsing belig. Die Christelike onderbou van die onderskeie gemeenskapsprojekte het by die empiriese studie, 'n definitiewe rol gespeel in die betrokkenheid, die omvang van die betrokkenheid en die volhoubaarheid van die projekte (Ries 2012:150, 154-155).

Hierdie gevolgtrekkings het die teorie versterk dat 'n Christelike of gemeentelike betrokkenheid ruim geleenthede bied vir die holistiese groei van al die individue (veranderingsagente en bemagtigdes) wat daarby betrokke raak.

Vanuit die oogpunt van 'n interkulturele ontmoeting, is 'n wesenlike skuif waarneembaar vanaf 'n primêre besorgdheid oor nood en/of hulpverlening na 'n vorm van 
verhoudingsbou waarbinne diegene na wie uitgereik word, bemagtig word en hulle menswaardigheid verhoog word (Ries 2012:167).

\section{Swart (2006) beskryf hierdie skuif as:}

the counterpoint to a contemporary society characterised by hard, macho (male) culture, aggression and egoism ... to $[a]$ new meaningful expressions of thinking, living, doing and relating in society as a whole. (bl. 230-231)

Die empiriese studie het bevestig dat Christelike gemeenskapsprojekte tot 'n besondere solidariteit en bondgenootskap met die samelewing se gemarginaliseerdes bydra. By sulke Christelike gemeenskapsprojekte gaan dit in die eerste plek nie om 'iets' wat vir of aan iemand gedoen word nie, maar eerder om die bevordering van 'n gevoel van saambehoort en omgee (Ries 2012:166-167).

Dit beteken egter nie dat alle liefdadigheidswerk noodwendig verkeerd of onnodig is nie. Daar is wel kontekste waarbinne sulke werk betekenisvol en selfs noodsaaklik is (vgl. Swart 2006:205). Dit beteken veel eerder dat die kerk opgeroep word om nie sy vertrekpunt vir betrokkenheid by nood- en/ of hulpverlening te vind nie.

Ware nood- en hulpverlening benodig nie alleen 'n transformasie of ommekeer van fisiese omstandighede nie, maar ook 'n transformasie van gesindheid. Deur die uitreik na die naaste, word nie net diegene na wie uitgereik word se menswaardigheid verhoog nie, maar veranderingsagente ontwikkel ook 'n groter sensitiwiteit vir diegene in nood.

Die klem van 'n gemeentelike betrokkenheid by armoede behoort veel eerder te val op wat Swart (2006:197) noem 'n 'spiritual renewal and deepening on which such a comprehensive transformation depends'.

By sodanige 'geestelike herlewing' speel evangelisasie steeds 'n deurslaggewende rol. Nie net gaan dit om 'n evangelisering van diegene na wie uitgereik word nie, maar ook die doelbewuste skep van 'n ruimte om geëvangeliseer te word deur diegene na wie uitgereik word.

Elmer (2006:148) skryf: 'Servanthood ... is, after all, an attitude that, when embedded within us, finds an appropriate way to express itself in every situation.'

Die vraag by Christelike uitreike na behoeftige gemeenskappe behoort dus nie te wees: Wat moet ek of my gemeente vir die armes gaan doen nie? Die vraag moet eerder wees: Hoe moet ek en my gemeente na ons naaste uitreik met wie ons as Christen so baie in gemeen behoort te hê?

\section{Erkenning Mededingende belange}

Die outeurs verklaar dat hulle geen finansiële of persoonlike verbintenis het met enige party wat hulle nadelig kon beïnvloed in die skryf van hierdie artikel nie.

\section{Outeursbydrae}

Die navorsing vir die artikel is gedoen deur J.R. (Universiteit van Stellenbosch) onder leiding van H.J.H. (Universiteit van Stellenbosch). Dit is gebaseer op J.R. se doktorale proefskrif en daar is saamgewerk in die verwerking daarvan in artikelvorm.

\section{Literatuurverwysings}

August, K.Th., 2000, 'Facilitating People-Centred Participatory Development as a Faith Based Organization', Nederduitse Gereformeerde Teologiese Tydskrif 41 (March \& June).

Batista, I., 1995, 'God's people in civil society', in R. Koegelenberg (ed.), The reconstruction and development programme (RDP): The role of the church, civil reconstruction and development programme (RDP): The role of the church, civil
society and NGOs, pp. 223-249, The World Council of Churches (WCC) Programme society and NGOs, pp. 2
Unit III, EFSA, Bellville.

Bevans, S.B. \& Schroeder, R.P., 2004, Constants in context: A theology of mission for today, Orbis Books, New York.

Elmer, D.H., 2006, Cross-cultural servanthood: Serving the world in Christlike humility, IVP Books, Downers Grove.

Goldsmith, S., 2002, Putting faith in neighborhoods: Making cities work through grassroots citizenship, Hudson Institute, Noblesville.

Instituut vir Geregtigheid en Versoening (IGV), 2009, SA reconciliation barometer survey report 2009, besigtig 08 Desember 2010, by http://www.ijr.org.za/aboutus.php

Keifert, P.R., 1992, Welcoming the stranger: A public theology of worship and evangelism, Fortress Press, Minneapolis.

Kotze, D.A., 1997, Development administration and management: $A$ holistic approach, Van Schaik, Pretoria.

Ries, J., 2012, 'Koinoniale en diakonale gestaltes van die missionale gemeente binne 'n konteks van multi-kulturaliteit', DTh proefskrif, Departement Praktiese Teologie en Missiologie, Universiteit van Stellenbosch.

Saayman, W., 1990, 'Intercultural Evangelisation', Missionalia 18(3), 308-319.

Samuel, V. \& Sugden, C., 1987, The church in response to human need, Eerdmans, Grand Rapids.

Schenk, C. \& Louw, H., 1995, 'People-centred community development', in R. Koegelenberg (ed.), The Reconstruction and Development Programme (RDP): The role of the church, civil society and NGOs (ed.), The WorldCouncil of Churches (WCC) Programme Unit III, pp. 175-195, EFSA, Bellville.

Shaw, R.D. \& Van Engen, C.E., 2003, Communicating God's word in a complex world: God's truth or hocus pocus?, Rowman \& Littlefield Publishers, New York.

Swart, I., 2006, The churches and the development debate: Perspectives on a fourth generation approach, Sun Press, Stellenbosch.

Trinity Evangelical Divinity School, 2012, Duane H. Elmer, PHD, viewed 17 February 2012, from web.tiu.edu/divinity/academics/faculty/Elmer

Volf, M., 1996, Exclusion and embrace: A heology exploration of identity, otherness, and reconciliation, Abingdon Press, Nashville. 